\title{
Integrating Universal Design for Learning in Schools: Implications for Teacher Training, Leadership and Professional Development
}

\author{
Frederic Fovet \\ Royal Roads University, Canada
}

\begin{abstract}
Universal Design for Learning (UDL) has gained momentum in $\mathrm{K}_{-12}$ education over the last decade. It enables educators to go beyond deficit model approaches to inclusion, and offers sustainable practices for the inclusion of diverse learners through intentional design for instruction and assessment. Promotion of UDL has taken many forms, from provincial projects to school communities of practice. A challenge remains, however, when comes time to widen implementation efforts. There remain specific challenges with regards to the scaling up of implementation strategies across schools and school boards. The process of management of change towards wider UDL buy-in is complex and leads to a necessary questioning of current professional development practices for in-service teachers, and of pre-service teaching in its present format. This chapter will explore these contemporary issues, as well as the wider reflection around leadership that must accompany this process.
\end{abstract}

Key Words: Universal Design for Learning; Inclusion; K-I2 Education, Professional Development; Pre-service Teacher Training; Leadership

\section{Context}

Inclusion in the $\mathrm{K}$ - $\mathrm{I} 2$ sector has been legislatively mandated in most Global North countries for almost two decades, but this imperative has rarely included details of how exactly Inclusion is to be achieved (de Bruin, 20I9). As a result the current landscape offers diverse, and at times contradictory, examples and models that seek to achieve Inclusion in the 
This is a limited preview of the chapter.

To read the full-text chapter, get access by purchasing this chapter or consider buying the complete book. If your library has subscription to EBSCOhost, the chapter including other chapters of the book can be accessed through your library.

This chapter is a part of the book, 'Innovations in Educational Leadership and Continuous Teachers' Professional Development' ISBN (paperback): 978-8I-948483-2-5; ISBN (ebook): 978-8I'

$$
\text { 948483-3-2 }
$$

Book DOI: https://dx.doi.org/ro.46679/isbn9788194848325

Chapter DOI: https://dx.doi.org/I0.46679/isbn978819484832513 
means to deliver. In order to do so, however, UDL cannot remain a mere conceptual notion, or a vague objective that remains unattainable. It must be placed at the very center of pre-service teaching, and its exploration must be pragmatic, detailed and realistic.

The urgency to make UDL the cornerstone of our institutional and societal move towards inclusion is not just felt in pre-service teacher training. UDL must also become a priority in professional development efforts within schools. This in-service training around UDL must be, once again, hands-on, exhaustive and empowering. As schools focus more PD around UDL, they may hence simultaneously become aware that the very nature and favour of PD needs to radically change in order to become more effective. The chapter has evidenced how the scope of this PD must change to allow more depth, richness, frequency, more hands-on implementation, and a format of delivery that mirrors the values it is trying to instill.

Lastly embracing UDL also means rethinking school leadership around the key concept of inclusive school climate that necessarily has transformative repercussions on many different practices and policies within schools. It is argued that UDL, beyond simply being an object of leadership reflection, in fact revolutionizes school leadership itself because it becomes a cathartic tool. Indeed, it compels school leaders to demonstrate in their approach to staff the very values they would like to see deployed with the learners. It brings to the forefront the issue of flexibility, accessibility and diversity as key values in leadership itself.

\section{References}

Abdullah, A., Ishak, M. Z., Peters, R. F., छ Kasan, A. (2019).Classroom Ethnography: Adapt or Adopt? International Journal of Humanities, Philosophy and Language, 2(8), $15-27$.

Allday, R. A., Neilsen-Gatti, S., छ Hudson, T. M. (2013). Preparation for inclusion in teachereducation pre-service curricula. Teacher Education and Special Education, 36, 298-3II

Anstead, M. (2016) Teachers Perceptions of Barriers to Universal Design for Learning. EdD Thesis. College of Education, Walden University. 
Ashby, C. (20I2). Disability studies and inclusive teacher preparation: A socially just path for teacher education. Research and Practice for Persons with Severe Disabilities, $37(2), 89-99$

Bacon, K. (2014) How a little idea called Universal Design for Learning has grown to become a big idea - elastic enough to fit every kid. Harvard Ed Magazine. Retrieved from: https://www.gse.harvard.edu/news/ed/r4/or/all-along

Bajaj, M. (20I8) Conceptualizing Transformative Agency in Education for Peace, Human Rights, and Social Justice. International Journal of Human Rights Education, 2(I).

Bogotch, I., Shields, C. M. (20I4). Do promises of social justice trump paradigms of educational leadership?. In Bogotch, I., Shields, C. M. (Eds.), International handbook of educational leadership and social (in)justice (pp. I-I2). Dordrecht, the Netherlands: Springer

Baptiste, M. (2019) No Teacher Left Behind: The Impact of Principal Leadership Styles On Teacher Job Satisfaction and Student Success. Journal of International Education and Leadership, 9 (I)

Blackwell, W. H., छ Rossetti, Z. S. (2014). The Development of Individualized Education Programs: Where Have We Been and Where Should We Go Now? SAGE Open.

Bline, K. (2014) Performing Critical Pedagogy Through Fireside Chats. International Journal of Critical Pedagogy, 5(2)

Bondie, R. S., Dahnke, C., \& Zusho, A. (2019). How Does Changing "One-Size-Fits-All" to Differentiated Instruction Affect Teaching? Review of Research in Education, $43(\mathrm{I}), 336-362$

Bridwell-Mitchell, E. N. (20I6). How peer learning in communities of practice enables and inhibits micro-institutional change. Organization Studies, 37, I6I- I92

Bunbury, S. (2019). Unconscious bias and the medical model: How the social model may hold the key to transformative thinking about disability discrimination. International Journal of Discrimination and the Law, I9 (I), 26-47

Calder Stegemann, K. J. (2013). Characteristics of teacher candidates who repeat practica and/or withdraw from the B.Ed. Program. Canadian Perspectives Journal, 3, I-27

Capp, M. (20I7) The effectiveness of universal design for learning: a meta-analysis of literature between 2013 and 2016.International Journal of Inclusive Education, $2 \mathrm{I}(8), 79 \mathrm{I}-807$

CAST. (2015). About universal design for learning. Retrieved from http://www.cast.org/our-work/about-udl.html

Cosier, M. (2016). Professional development in inclusive school reform: The need for critical and functional approaches. In M. Cosierछ C. E. Ashby (Eds.), Enacting change from within: Disability studies meets teaching and teacher education (pp. 295-313). New York, NY: Peter Lang Publishing, Inc.

Cosier, M., छै Pearson, H. (20I6). Can we talk? The underdeveloped dialogue between teacher education and disability studies. $S A G E$ Open, $6(\mathrm{I})$ 
Courtad, C. (2019) Making Your Classroom Smart: Universal Design for Learning and Technology. Smart Education and e-Learning 20I9, 50I-510

Craig, S., Smith, S.,छ Frey, B. (2019) Professional development with universal design for learning: supporting teachers as learners to increase the implementation of UDL.Professional Development in Education

Crispel, O. EKKasperski, R. (20I9). The impact of teacher training in special education on the implementation of inclusion in mainstream classrooms. International Journal of Inclusive Education, I-I2.

Dalton, E. M., Lyner-Cleophas, M., Ferguson, B. T., E McKenzie, J. (2019). Inclusion, universal design and universal design for learning in higher education: South Africa and the United States. African journal of disability, 8, $5 \mathrm{I} 9$.

de Bruin, K. (2019) The impact of inclusive education reforms on students with disability: an international comparison. International Journal of Inclusive Education, $23(7-8)$, 8II826

DeMatthews, D. E., Kotok, S., Eु Serafini, A. (2019). Leadership Preparation for Special Education and Inclusive Schools: Beliefs and Recommendations From Successful Principals. Journal of Research on Leadership Education

Derby, J. (20I6). Confronting ableism: Disability studies pedagogy in preservice art education. Studies in Art Education, 57(2), I02-II9.

Eğriboyun, D. (20I9). The transactional leadership behaviours, learning organization dimensions and job motivation in the schools. Advances in Social Sciences Research Journal, 6(3), 50-82

Ellis, G. (2018) Social Model Thinking about Disability through Picturebooks in Primary English. CLELE Journal, article 3. Retrieved from: http://clelejournal.org/article3-social-model-thinking/

Evmenova, A. (2018) Preparing Teachers to Use Universal Design for Learning to Support

Diverse Learners. Journal of Online Learning Research, 4(2), I47’-17I

Fovet, F. (in print) Developing an Ecological Approach to Strategic UDL Implementation in Higher Education. Journal of Education and Teaching

Fovet, F. (2020) Beyond Novelty - "Innovative" Accessible Teaching as a Return to Fundamental Questions Around Social Justice and Reflective Pedagogy. In: S. Palahicky (Ed.) Enhancing Learning Design for Innovative Teaching in Higher Education. IGI Global: Hershey, PA

Fovet, F. (2016) Doing what we preach: examining the contradictions of the UDL discourse in faculties of education. Paper presented at the 2017 AHEAD Ireland Conference, Dublin, March

Freedman, J., Applebaum, A., Woodfield, C., छ̋ Ashby, C. (2019) Integrating Disability Studies Pedagogy in Teacher Education. Journal of Teaching Disability Studies, I.

Friesen, (2018, September 18) A Future Wanting to Emerge. EdCan. Retrieved from: https://www.edcan.ca/articles/a-future-wanting-to-emerge/ 
Gaikhorst, L., März, V., du Pré, R., छ̇ Geijsel, F. (2019) Workplace conditions for successful teacher professional development: School principals' beliefs and practices. European Journal of Education, 54, 605- 620

Garsten, C., छॄ Nyqvist, A. (Eds.) (2013) Organisational anthropology: doing ethnography in and among complex organisations. New York: Pluto Press.

Gilham, C. M., छJ Tompkins, J. (20I6). Inclusion reconceptualized: Pre-service teacher education and disability studies in education. Canadian Journal of Education, 39(4)

Gillberg, C., छ Pettersson, A. (20I9) Between duty and right: disabled schoolchildren and teachers' ableist manifestations in Sweden. Disability E' Society, 34(9-10), I668-1673

Goodwin, A.L. (2020) Globalization, Global Mindsets and Teacher Education. Action in Teacher Education, 42(I), 6-18

Hallam, P. R., Smith, H. R., Hite, J. M., Hite, S. J., \&ु Wilcox, B. R. (2015). Trust and Collaboration in PLC Teams: Teacher relationship, principal support, and collaborative benefits. NASSP Bulletin, 99(3), 193-216.

Heroux, J. R. (20I7). Infusing disability studies within special education: A personal story. Review of Disability Studies: An International Journal, I3(I).

Hjörne, E., छ̋ Säljö, R. (20I9) Teaching and learning in the special education setting: agency of the diagnosed child. Emotional and Behavioural Difficulties, 24(3), 224-238

Hogan, A. (2019) Social and medical models of disability and mental health: evolution and renewal. $C M A J$, I9r(I) Eı6-Eı8

Hogle, P. (2019, March 20) Improve UX with Accessible, Inclusive eLearning Design. Learning Solutions. Retrieved from:

https://learningsolutionsmag.com/articles/improve-ux-with-accessible-inclusiveelearning-design

Institute for Human Centered Design. (20I7). History of universal design. Boston, MA: IHCD. Retrieved from:

https://web.archive.org/web/20I70929034659/http://www.humancentereddesign. org/universal-design/history-universal-design

Israel, M., Ribuffo, C., छ Smith, S. (2014). Innovation Configuration Universal Design for Learning Recommendations for Teacher Preparation and Professional Development. Office of Special Education Programs, U.S. Department of Education, (Ic), I-38.

Juvonen, J., Lessard, L., Rastogi, R., Schacter, H., ES ayre Smith, D. (20I9) Promoting Social Inclusion in Educational Settings: Challenges and Opportunities. Educational Psychologist, 54(4), 250-270,

Kars, M., E Inandi, Y. (20I8). Relationship between school principals' leadership behaviors and teachers' organizational trust. Eurasian Journal of Educational Research, 74, I 45 'I 64

Keay, J., Carse, N., छ J Jess, M. (20I9) Understanding teachers as complex professional learners. Professional Development in Education, 45(I), 125-137 
Kelly, J. (20I3). Professional learning communities: The emergence of vulnerability.Professional Development in Education, 39(5), 862-864

Kelly, J., \& Cherkowski, S. (2015). Collaboration, collegiality, and collective reflection: A case study of professional development for teachers. Canadian Journal of Educational Administration and Policy, I69, I-27.

Keon, D. M. (2020). 'Soft barriers' - The impact of school ethos and culture on the inclusion of students with special educational needs in mainstream schools in Ireland. Improving Schools.

Kirby, M. (2017) Implicit Assumptions in Special Education Policy: Promoting Full Inclusion for Students with Learning Disabilities. Child Youth Care Forum, 46,I75-I9I. Retrieved from: https://teachingisintellectual.com/wpcontent/uploads/2019/05/Kirby-2016.pdf

Kocaballi, A., Laranjo, L., छ Coiera, E., (2019) Understanding and Measuring User Experience in Conversational Interfaces.Interacting with Computers, $3 I(2)$, I92207 ,

Kulkarni, S. S. (20I9). Towards a critical disability studies model of teacher education. In K. Ellis, R. Garland-Thomson, M. Kent, $छ$ R. Robertson (Eds.). Interdisciplinary approaches to disability: Looking towards the future (Vol. 2). Abingdon-onThames, UK: Routledge.

Kumari, A.M., \& Mishra, A. (20I7) Universal design for education in regular schools: a preliminary study. International Journal of Development Research, 7, art. 9743. Retrieved from: https://www.journalijdr.com/universal-design-education-regularschools-preliminary-study

Lambrecht, J., Lenkeit, J., Hartmann, A., Ehlert, A., Knigge, M., छु Spörer, N. (2020) The effect of school leadership on implementing inclusive education: how transformational and instructional leadership practices affect individualised education planning. International Journal of Inclusive Education,

Lautenbach, F., \& Heyder, A. (2019) Changing attitudes to inclusion in preservice teacher education: a systematic review.Educational Research, 6I(2), 23I-253

Louws, M. L., Meirink, J. A., van Veen, K., छ van Driel, J. H. (20I7). Exploring the relatiobetween teachers' perceptions of workplace conditions and their professional learning goals. Professional Development in Education, 43, 770- 788

Lowrey, K., Classen, A., छु Sylvest, A. (2019). Exploring Ways to Support Preservice Teachers' Use of UDL In Planning and Instruction. Journal of Educational Research EF Practice, $9(\mathrm{I}), 26 \mathrm{I}-28 \mathrm{I}$

Maciver, D., Rutherford, M., Arakelyan, S., Kramer, J. M., Richmond, J., Todorova, L., Romero-Ayuso, D., Nakamura-Thomas, H., Ten Velden, M., Finlayson, I., O'Hare, A., EJ Forsyth, K. (20I9). Participation of children with disabilities in school: A realist systematic review of psychosocial and environmental factors. PloS one, I4(I) 
Mader, J. (20I7, March I) How Teacher Training Hinders Special-Needs Students. The Atlantic. Retrieved from:

https://www.theatlantic.com/education/archive/20I7/03/how-teacher-training, hinders-special-needs-students/518286/

Manrique, A.L., Dirani, E., Frere, A., Moreira, G., \& Arezes, P. (2018). Teachers' perceptions on inclusion in basic school. International Journal of Educational Management, 33

Martin, N., Wray, M., James, A., Draffan, E.A., Krupa, J., छ Turner, P. (2019). Implementing Inclusive Teaching and Learning in UK Higher Education - Utilising Universal Design for Learning (UDL) as a Route to Excellence. Society for Research into Higher Education

McConnell, T. J., Parker, J. M., Koehler, M. J., छ Lundenberg, M. A. (2013). Virtual professional learning communities: Teachers perceptions of virtual versus facetoface professional development. Journal of Science Education and Technology, 22(3), $267-277$

Menconi, M.E, छ Grohmann, D. (2018) Participatory retrofitting of school playgrounds: Collaboration between children and university students to develop a vision. Thinking Skills and Creativity,29,71-86

Meyer, A., Rose, D., EJ Gordon, D. (2014). Universal design for learning: Theory and practice. Wakefield, MA: CAST Professional Publishing.

Murphy, A. (20I7, October 26) Embracing the UDL Classroom: 4 Steps To A More Flexible Education. EdTech. Retrieved from: https://edtechmagazine.com/ki2/article/20I7/Io/4-steps-implement-universaldesign-learning-classroom

Nation, M., Christens, B., Bess, K., Shinn, M., Perkins, D., छ Speer, P. (2020) Addressing the problems of urban education: An ecological systems perspective.Journal of Urban Affairs

National Council on Disability (2018) The Segregation of Students with Disabilities. IDEA Series. NCD: Washington DC. Retrieved from: https://ncd.gov/sites/default/files/NCD_Segregation-SWD_508.pdf

Ok, M., Rao, K., Bryant, B., छै McDougall, D. (20I7)Universal Design for Learning in Pre-K to Grade I2 Classrooms: A Systematic Review of Research. Exceptionality, 25(2), II6-I38

Oliver, M. (2013) The Social Model of Disability: Thirty Years on.Disability E Society, $28(7), 1024-1026$

Owen, S. (20I4).Teacher professional learning communities: Going beyond contrived collegiality toward challenging debate and collegial learning and professional growth. Australian Journal of Adult Learning, 54(2), 54 
Pearson, H. (20I6) The impact of Disability Studies curriculum on education professionals' perspectives and practice: Implications for education, social justice, and social change. Disability Studies Quarterly, 36(2)

Pozas, M., Letzel, V., छ̋ Schneider, C. (2020) Teachers and differentiated instruction: exploring differentiation practices to address student diversity. Journal of Research in Special Educational Needs

Ralabate, P. (20II) Universal Design for Learning: Meeting the Needs of All Students. Leader, I6(I0), I4-17

Rao, K., छॄMeo, G. (20I6). Using Universal Design for Learning to Design Standards-Based Lessons. SAGE Open.

Rashid, M., Caine, V., EGGoez, H. (2015) The Encounters and Challenges of Ethnography As Methodology in Health Research.International Journal of Qualitative Methods, I4, I-I6

Rees, K. (20I7). Models of disability and the categorisation of children with severe and profound learning difficulties: Informing educational approaches based on an understanding of individual needs. Educational and Child Psychology, 34, 30-39

Rodd, P., छ Sanders, K. (2019). The imperative of critical pedagogy in times of cultural austerity: A case study of the capacity to reimagine education as a tool for emancipation. New Zealand Sociology, 33,33-55

Roswitha, R., Antje, W., Gertrud, L., EPPhilipp, K. (2019) Pre-service Teachers' Beliefs About Inclusive Education Before and After Multi-Compared to Monoprofessional Co-teaching: An Exploratory Study. Frontiers in Education, 4, IOI

Shah, N. (20I2). Study finds districts buying into universal design: But many educationleaders still aren't sure what UDL is. Education Week, $3{ }_{3}(32)$

Smale-Jacobse, A., Meijer, A., Helms-Lorenz, M., Maulana, R. (20I9) Differentiated Instruction in Secondary Education: A Systematic Review of Research Evidence. Frontiers in Psychology, Io, 2366

Smith, P., छ Bell, L. (20II). Transactional and transformational leadership in schools in challenging circumstances: a policy paradox. Management in Education, 25(2), $58-$ 6I

Smith, S. J., Rao, K., Lowrey, K. A., Gardner, J. E., Moore, E., Coy, K., Marino, M., EWWojcik, B. (20I9). Recommendations for a National Research Agenda in UDL: Outcomes From the UDL-IRN Preconference on Research. Journal of Disability Policy Studies, 30(3), I74-185.

Song, H. (2012). The role of teachers' professional learning communities inthe context of curriculum reform in high schools. Chinese Education EF Society, 45(4), 8I-95.

Stanford, B., छै Reeves, S. (2009). Making It Happen: Using Differentiated Instruction, Retrofit Framework and Universal Design for Learning. TEACHING Exceptional Children / TEACHING Exceptional Children Plus. 
Sulaimani, M., छॄ Gut, D. (2019) Hidden Curriculum in a Special Education Context: The Case ofIndividuals With Autism. Journal of Educational Research and Practice, 9(I), 30-39

Svensson, I., Nordström, T., Lindeblad, E., Gustafson, S., Björn, M., Sand, C., AlmgrenBäck, G., ENNilsson, S. (2019) Effects of assistive technology for students with reading and writing disabilities.Disability and Rehabilitation: Assistive Technology

Swaffield, S.,E Major, L. (2019) Inclusive educational leadership to establish a co-operative school cluster trust? Exploring perspectives and making links with leadership for learning.International Journal of Inclusive Education, 23(II), II49-1I63

Tobia, E. F., छ Hord, S. M. (2012). I am a professional: Learning communities elevateteachers' knowledge, skills, and identity. Journal of Staff Development, 33(3), I6-26

Third Pan-Canadian Conference on UDL (2019) Connecting the Dots - Sharing Promising Practices across Country. Retrieved from: www.udlcanada.ca

Trent, J. (2019) Building Access: Universal Design and the Politics of Disability.Journal of American History, I05(4), I042-1043

Valle, J. W., छ Connor, D. J. (20II). Rethinking disability: A disability studies approach to inclusive practices. New York, NY: McGraw-Hill

Van Boxtel, J.,छ Sugita, T. (2019) Exploring the implementation of lesson-level UDL principles through an observation protocol. International Journal of Inclusive Education

van Diggelen, M.R., Doulougeri, K.I., Gomez-Puente, S.M., Bombaerts, G., Dirkx, K., छซ Kamp, R.(20I9)Coaching in design-based learning: a grounded theory approach to create a theoretical model and practical propositions. International Journalof Technologyand Design Education

van Geel, M., Keuning, T., Frèrejean, J., Dolmans, D., van Merriënboer, J., EVVisscher, A. (2019) Capturing the complexity of differentiated instruction.School Effectiveness and School Improvement, 30 (I), $5 \mathrm{I}-67$

Van Lankveld, T., Schoonenboom, J., Volman, M., Croiset, G., EBBeishuizen, J. (20I7). Developing a teacher identity in the university context: A systematic review of the literature. Higher Education Research Eं Development,36(2), 325-342.

van Veen, K., Zwart, R., E'Meirink, J. (20I2). What makes teacher professional development effective? A literature review. In M. Kooyछ̋ K. van Veen (Eds.), Teacher learning that matters: International perspectives (pp. 3-2I). New York, NY: Routledge.

Vitelli, E. M. (20I5). Universal design for learning: Are we teaching it to pre-service generaleducation teachers? Journal of Special Education Technology, 30, 166-I78

Wang, S. (2019) School heads' transformational leadership and students' modernity: the multiple mediating effects of school climates. Asia Pacific Educational Review, 20, 329-34I 
Williams, V., Tarleton, B., Heslop, P., Porter, S., Sass, B., Blue, S., Merchant, W., ĖMasonAngelow, V. (2018) Understanding disabling barriers: a fruitful partnership between Disability Studies and social practices? Disability E' Society, 33(2), I57-174

Witterholt, M., Goedhart, M., छु Suhre, C. (20I6). The impact of peer collaboration on Teachers' practical knowledge. European Journal of Teacher Education, 39(I), I26I43

Yngve, M., Lidström, H., Ekbladh, E., EJHemmingsson, H. (2019) Which students need accommodations the most, and to what extent are their needs met by regular upper secondary school? A cross-sectional study among students with special educational needs. European Journal of Special Needs Education, 34(3), 327-34I

You, S., Kim, E., EJ Shin, K. (2019) Teachers' Belief and Efficacy Toward InclusiveEducation in Early Childhood Settings in Korea. Sustainability, II, I489 